\title{
KATAK ANAK BERACUN SEBAGAI SUMBER IDE PENCIPTAAN BUSANA PESTA SIANG ANAK
}

\author{
Septianti \\ Jurusan DKV, Fakultas Teknik, Universitas Maarif Hasyim Latif, \\ ceptianti@gmail.com, septainti@dosen.umaha.ac.id, 085729366061
}

\begin{abstract}
Frogs are one of the animals that are not liked by society in general. Pamor this animal far compared to other tetrapods. One of them is poisonous dart frog which is an idea as a form of child psychology or thought that frogs are not disgusting or ugly creatures but have their own charm while introducing different types of frogs. The embodiment of this work is in the form of poisoned dart frog motifs that are manifested into children's day party outfits. To realize this, several methods are needed in the creation of works, which pay attention to the aesthetic value of fashion by taking into account the design, motives, and beauty values of clothing in addition to the ergonomic aspects, namely the comfort of the child when using clothing and the semiotics of the markings on the clothing. In creating this work 10 types of poisonous frog arrows are the most dangerous in the genus that have striking and attractive colors. The dyeing process itself uses naphtol and indigosol dyes. After carrying out all these processes, the process of materializing the work begins and results in a children's day party outfit, which originates from the idea of a poison dart frog.
\end{abstract}

Keywords: frog, poisonous, party clothes, children, fashion

\begin{abstract}
ABSTRAK
Katak merupakan salah satu hewan yang tidak disukai oleh masyarakat pada umumnya. Pamor hewan ini jauh jika dibandingkan tetrapoda lain. Salah Satunya katak anak panah beracun yang menjadi ide sebagai bentuk psikologi anak atau pemikiran bahwa katak bukan makhluk yang menjijikan maupun jelek namun memiliki daya tarik tersendiri sekaligus memperkenalkan adanya jenis katak yang berbeda dengan lainya.Perwujudan karya ini berupa motif katak anak panah beracun yang diwujudkan ke dalam busana pesta siang anak. Untuk mewujudkan hal tersebut maka, perlu digunakan beberapa metode dalam penciptaan karya, yang memperhatikan nilai estetika pada busana dengan memperhitungkan desain, motif, dan nilai keindahan pada busana disamping aspek ergonomi, yaitu kenyaman anak saat menggunakan busana dan semiotika nilai tanda yang ada pada busana. Dalam penciptakan karya ini digunakan 10 jenis katak anak panah beracun yang paling berbahaya di genusnya yang memiliki warnawarna yang mencolok dan menarik. Proses pewarna sendiri menggunakan pewarna naphtol dan indigosol. Setelah melakukan semua proses tersebut mulai dilakukan proses perwujudan karya dan menghasilkan busana pesta siang anak yang bersumber ide dari katak anak panah beracun.

Kata kunci : katak, beracun, busana pesta, anak, fashion
\end{abstract}




\section{PENDAHULUAN}

Usia anak-anak adalah usia untuk belajar dan mencoba berbagai hal, termasuk dalam cara mereka menentukan pilihan dalam berbusana. Sama halnya dengan orang dewasa, anak-anak memerlukan busana sebagai sarana bersosialisasi dengan lingkungan sekitarnya. Salah satu bentuk sosialisasi adalah anak dengan menghadiri atau mengundang pada acara pesta seperti ulang tahun dan acara resmi yang sering kali orang tua mengajak anaknya untuk ikut serta. Berdasarkan hal tersebut, dalam pembuatan karya ini penulis akan membuat busana anak berdasarkan fungsinya, yaitu sebagai busana pesta siang hari. Alasan mengambil busana pesta siang anak dalam karya penciptaan ini adalah untuk merancang busana dengan memperhatikan nilai estetika dan juga nilai ergonomi, yang akan dikenakan pada anak diwujudkan dengan beberapa teknik di kriya tekstil.

Busana pesta memiliki berbagai jenis model sesuai dengan tempat dan waktu penggunaannya. Penulis mengambil busana pesta siang karena anak-anak lebih aktif di siang hari dan jarang diajak saat acara pada malam hari. Dengan menampilkan karya yang tidak terlalu mencolok dan model yang tidak rumit dimaksudkan agar dapat memberikan rasa nyaman dan bebas bergerak pada anak. Seiring perubahan zaman, busana mulai berkembang bentuk, motif, dan warna. Berdasarkan hal tersebut muncullah ide katak anak panah beracun (Poison Dart Frog) sebagai ide penciptaan busana pesta siang anak. Ide ini berawal saat melihat katak saat di sawah dan pada musim hujan. Hal ini membuat penulis tertarik melihat hewan yang satu ini, katak memiliki bentuk yang berbeda dengan kodok, akan tetapi sama-sama memiliki kulit yang belendir dan membuat beberapa orang yang melihat merasa takut, tak terkecuali untuk anak-anak.

Pada umumnya, masyarakat Indonesia dan anak-anak tidak menyukai katak atau kodok. Pamor hewan tersebut kalah jauh dibandingkan tetrapoda lain seperti burung, reptil apalagi mamalia. Padahal di luar sana seperti di Surabaya adanya katak raksaksa yang berjenis bull frog dengan diameter $22 \mathrm{~cm}$ yang dijual dengan harga mahal, sementara itu adanya komunitas katak dan kodok hias di Indonesia yang memperlihatkan berbagai jenis katak menjadi primadona "aqua tank", katak dijadikan hewan peliharaan, sebut saja, katak Bertanduk Ornamen, Katak Pohon Mata Merah, bahkan Katak Beracun sekalipun, (2013: 1).

Penulis mengambil katak panah beracun (Poison Dart Frog) sebagai ide penciptaan diharapkan akan memberikan psikologi anak atau pemikiran bahwa katak bukan makhluk yang menjijikan maupun jelek, namun memiliki daya tarik tersendiri bila diamati lebih jauh, serta sebagai sarana memperkenalkan bahwa ada katak unik dan berbeda dengan katak pada umumnya.

Katak dan kodok merupakan dua jenis yang sama namun memiliki perbedaan. Jenis katak yang dipenuhi dengan bintik-bintik kasar seperti kutil, membuatnya nampak tidak cantik serta tubuhnya kadang mengeluarkan bau tidak sedap itu yang sering kali disebut dengan kodok (Toads). Kodok dapat dijumpai dimanamana. Kaki kodok relatif pendek hingga pergerakan tidak setinggi katak, sedangkan katak memiliki kulit yang halus, tidak memiliki bintik-bintik yang jelas seperti kodok, sebagian besar bertubuh ramping (walaupun ada yang memiliki tubuh gemuk namun berbeda dengan kodok). Katak (Frogs)relatif memiliki kaki yang panjang hingga memungkinkan katak 
melompat jauh dan memiliki berbagai jenis sesuai habitatnya. (Kay, 2004)

Secara visual katak panah beracun memiliki kulit yang halus dan warna yang mencolok. Tidak seperti kebanyakan katak lainnya, spesies ini aktif pada siang hari dan sering menunjukan tubuh warna yang cerah. Katak panah beracun memiliki warna-warna yang menarik seperti katak anak panah beracun emas. Walaupun beracun ia dapat digunakan untuk mengobati penderita serangan jantung. Oleh karenanya, spesies ini hampir terancam punah. Amfibi ini sering disebut dengan katak panah oleh para pribumi Indian yang sering menggunakan katak panah sebagai bahan meracuni ujung panahnya.

Dari uraian di atas maka pengambilan tema katak anak panah beracun sebagai sumber ide penciptaan busana pesta siang anak. Dalam penciptaannya katak anak panah beracun ini digunakan sebagai sumber inspirasi pembuatan motif dan acuan dalam pemilihan warna yang akan dilakukan melalui proses pembatikan, tye-die, bordir, dan teknik hias kreasi yang akan dibentuk menjadi busana pesta siang anak.

\section{METODE PENCIPTAAN}

Metode yang digunakan dalam menciptakan desain yang akan diterapkan pada busana pesta anak-anak digunakan teknik yang telah dipelajari. Secara sistematis menurut (Gustami, 2007: 329-332) dalam konteks metodologi, terdapat tiga tahap penciptaan seni kriya, yaitu Eksplorasi (pencarian sumber ide, konsep, dan landasan penciptaan), Perancangan (rancangan desain karya), dan Perwujudan (pembuatan karya).Analisis tiga tahap penciptaan itu dapat diurai menjadi enam langkah proses penciptaan karya, yaitu:

Pertama, tahap eksplorasi, meliputi : a). Langkah pengembangan jiwa, pengamatan lapangan dan mengali sumber referensi dan informasi tentang katak anak panah beracun, untuk menemukan tema ataupun berbagai persoalan yang akan dijadikan sebagai rumusan masalah. b). Langkah Kedua, mencari landasan teori, sumber, dan referensi serta acuan visual mengenai katak anak panah, yang kelak akan menjadi landasan visualisasi gagasan kreatif ke dalam bentuk sket atau gambar teknik yang akan diwujudkan dalam bentuk 2 maupun 3 dimensi.

Kedua, tahap perancangan, meliputi a). Langkah ketiga, yakni tahapan perancangan untuk menuangkan ide atau gagasan dari deskripsi verbal katak anak panah beracun menjadi bentuk visual 2 dimensional yang dipertimbangkan dari berbagai aspek kriya. b). Langkah keempat, adalah visualisasi gagasan rancangan sketsa alternatif terpilih busana dan motif katak anak panah yang telah disiapkan yang telah menjadi bentuk prototipe.

Ketiga, tahapan perwujudan, a) tahapan perwujudan yang pelaksanaannya berdasarkan desain busana yang telah dipilih dan dianggap sempurna, termasuk penyelesaian akhir atau finishing dan sistem kemasan.Teknik utama dalam pembuatan menggunakan pengelolahan kain dengan batik dan ikat celup ekspresi. Dalam pemberian perlengkap pada busana digunakan bordir dan teknik hias kreasi. Sementara pengerjaan finishing busana dikerjakan dengan teknik kelim som sembunyi, kelim veston, obras, dan wollsum. b). Langkah keenam, yaitu melakukan penilaian atau evaluasi terhadap hasil perwujudan yang sudah diselesaikan. Dengan demikian, hasil yang akan diwujudkan dapat melihat kualitas material, teknik kontruksi, estetik, dan fungsi sosial kulturnya.

Teori

1) Estetika 


\begin{abstract}
Dalam menciptakan suatu karya diperlukan pendekatan estetika yang menekankan pada aspek-aspek seni dan desain dengan daya tarik estetik. Daya tarik estetik dapat muncul dengan aspek bentuk, kandungan isi, dan ungkapan emosi yang akan dituangkan ke dalam karya seni ini. Dalam pembentukan karya menggunakan aspek desain busana yang akan memperlihatkan keindahan dari unsur desain dan prinsip desain yang akan diterapkan pada karya busana pesta siang anak.
\end{abstract}

\section{2) Ergonomi}

Pendekatan ergonomi yang akan digunakan dalam perancangan model busana tentu saja memperhatikan aspek kenyamanan pemakainya. Dalam menuangkan suatu rancangan busana perlu memperhatikan, aspek kenyamanan pemakai (ergonomi), demikian pendapat (Gustami, 2007: 331). Aspek-aspek yang akan digunakan dalam pembuatan busana dengan memperhatikan keseimbangan antar ukuran anak yang akan digunakan, pola, desain, dan proporsi yang sesuai dengan anak-anak.

Dalam buku Teknik Menggambar Mode Busana (Goes Poespo, 2000). Pendekatan ini digunakan dalam pemilihan busana anak yang sesuai agar anak-anak merasa nyaman dan senang saat memakai hasil rancangan busana yang akan diciptakan. Hal ini penting dalam pemilihan bahan dan ukuran anak, sehingga menghasilkan karya yang nyaman saat digunakan.

\section{3) Busana}

berdasarkan kesempatanya ada beberapa macam busana, akan tetapi dalam penciptaan tugas akhir ini penulis mengambil busana pesta anak sebagai karya tugas akhir. Busana pesta adalah busana yang lebih mengutamakan keindahan. Macam-macam busana pesta menurut kesempatan pemakainya adalah :

a. Busana pesta pagi dan siang, busana ini memiliki model yang tidak terlalu rumit dengan bahan kain tidak terlalu berkilau dan warna tidak terlalu mencolok.

b. Busana pesta koktail, busana memiliki bahan yang lebih baik dari pada busana pesta pagi dan siang dengan bahan kain yang berkilau dan warna boleh yang mencolok namun, perhiasan tidak terlalu berkilau.

c. Busana pesta malam, busana ini merupakan busana yang mewah baik penampilan desain, warna, dan bahannya. Busana ini serba gemerlap dan elegan.

d. Busana pesta gala, busana ini amat mewah dari warnadan bahan yang digunakan, busana ini digunakan pada event fashion.

e. Busana pesta Fantasi merupakan busana yang dibuat sebagai hasil daya cipta, khayalan atau angan-angan, gagasan, ide atau inspirasi seseorang yang digunakan pada saat pesta kostum dan lain-lain. (Arifah A Riyanto, 2002: 106-116)

Dalam pembuatan karya busana anak mengambil busana pesta siang yang tidak terlalu mencolok dan penggunaan bahan yang sesuai dengan kenyaman anak yang akan memakainya.

\section{4) Semiotika}

Semiotika sendiri ilmu yang mempelajari tentang tanda-tanda (the study of signs), demikian penegasan (Berger, 2010: 4-5). Semiotika berkaitan dengan semua hal yang dapat dimaknai sebagai tanda. Suatu tanda adalah segala sesuatu yang dapat dimaknai.Dari hal ini penulis mengambil semiotika sebagai 
pendekatan dalam menciptakan karyanya. Teori Charles Sander Peirce digunakan sebagai pengamatan terhadap penciptaan karya seperti warna, bahan, garis desain dan semua yang memiliki tanda.

Tanda juga digunakan sebagai hubungan yang tidak efisien menjadi efisien dan Pierce juga mengaitkan adanya tanda sebagai latar belakang terjadi keadaan, demikian penegasan (Agus Sachari, 2002: 65). Menurut Pierce, tanda memiliki tiga unsur yang saling berhubungan, yaitu

a. Ikon, tanda yang antara tanda dengan acuannya ada hubungan kemiripan. Contohnya peta dan wilayah geografi, foto dengan objeknya, lukisan dengan gagasannya).

b. Indeks, tanda yang memiliki hubungan sebab akibat atau disebut juga tanda sebagai bukti. Contohnya, asap ada api, jejak telapak kaki menunjukan orang yang melewati tempat itu.

c. Simbol, tanda berdasarkan perjanjian yang telah disepakati bersama. Contohnya, gerakan tubuh atau anggukan kepala sebagai tanda setuju).

Tiga unsur tanda diatas digunakan sebagai data acuan dalam pemilihan warna, garis desain, penggunaan aksesoris, motif, dan semua yang memiliki aspek tanda.

\section{HASIL DAN PEMBAHASAN}

Pengunaan data acuan nantinya digunakan sebagai perpaduan komposisi warna dan bentuk yang nantinya dituangkan kedalam desain busana itu sendiri. Selain itu, penulis juga menggunakan nama katak anak panah beracun yang terdapat pada data acaun sebagai judul karyanya. Adapun bagian penting yang dijadikan sebagai objek analisis melalui sudut pandang berikut:

1. Katak Anak Panah Beracun (Poison Dart Frog)

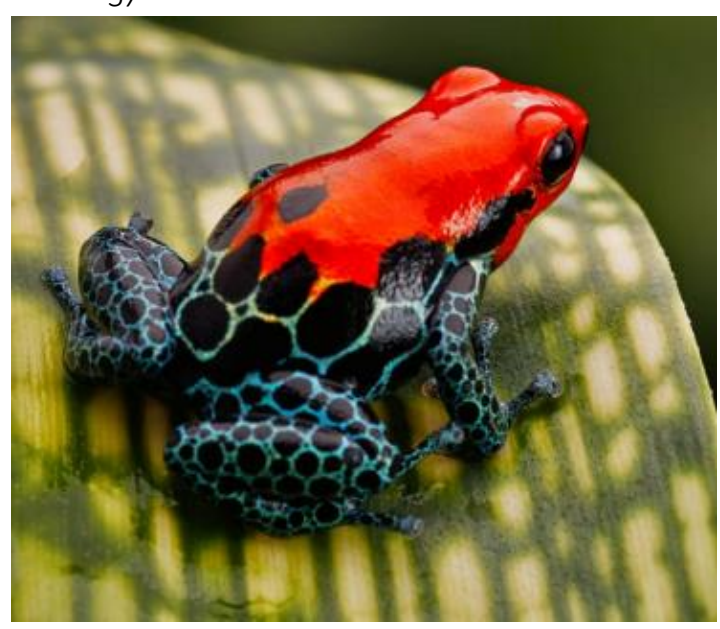

Gambar 1. Yuki, Red-backed Poison Frog, 2011 (Sumber:(Yuki, 2011))

Di atas merupakan salah satu gambar dari jenis katak anak panah beracun memiliki beraneka ragam jenis, kebanyakan dari jenisnya berukuran kecil dan memiliki warna-warna yang mencolok. Warna yang mencolok memiliki maksud tertentu, katak ini memberi tanda untuk berhati-hati terhadapnya. Pengambil jenis katak anak panah beracun hanya 10 jenis yang paling berbahaya dan yang menurut penulis memiliki warna yang menarik. Pembuatan karya ini, mengambil warnanya yang akan diterapkan pada busana dan nama katak anak panah beracun sebagai judul karyanya.

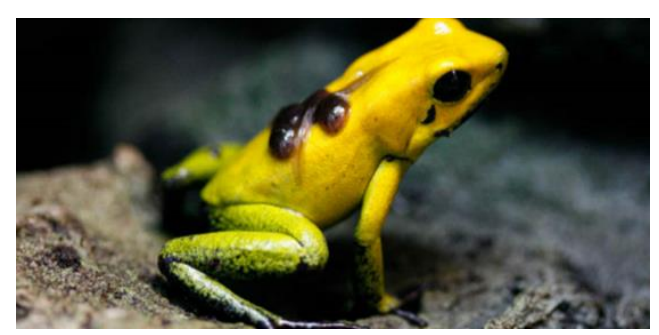

Gambar 2. Yuki,Black Legged Dart Frog, 2011 (Sumber:(Yuki, 2011)) 
Seperti gambar data acuan yang diamati katak ini memiliki keunikan, yaitu membawa berudunya diatas punggungnya yang telah diberi lendir. Miliki tubuh yang lebih pendek, kaki yang berselaput, kulit lebih licin, dan tungkai belakang panjang untuk berenang dan melompat. Kebanyakan katak memiliki mata menonjol dan gigi rahang diatas. Dalam penciptaan tugas akhir ini penulis menampilkan warna, bentuk, dan telur katak sebagai bentuk hiasan busana pesta siang anak.

\section{Busana Pesta Siang Anak}

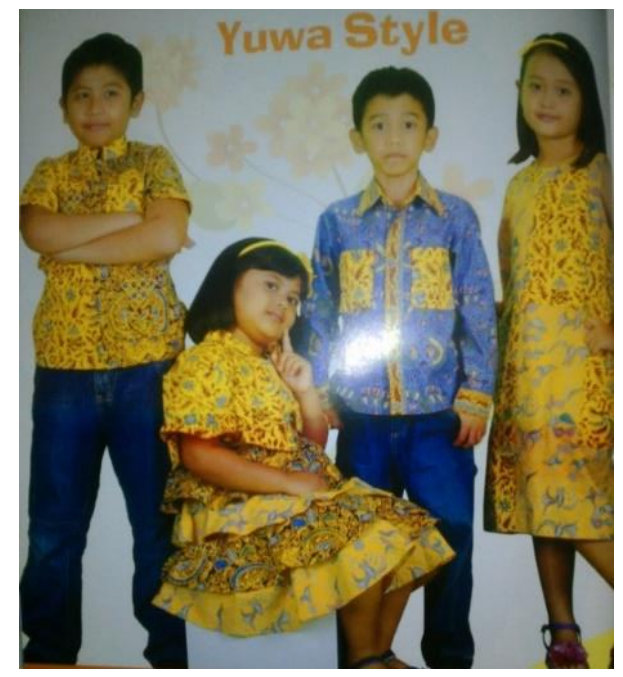

Gambar 3. Dwi Adi Kusuma, Yuwa Style, 2013 (Sumber:(Kusuma, 2013: 16))

Busana pesta merupakan busana khusus yang dikenakan untuk acara-acara spesial. Pada gambar terdapat berbagai macam busana pesta, tetapi penulis mengambil beberapa jenis data acuan sebagai proses dalam perancangan dan perwujudan busana pesta siang anak. Prosesnya dilakukan eksplorasi dalam pemilihan bahan seperti yang terlihat pada gambar acuan, busana pesta memiliki beberapa karakteristik yang berbeda dari busana sehari-hari. Untuk menampilkan kesan yang bagus, cantik, dan elegan perlu memperhatikan bahan yang akan digunakan agar anak-anak merasa nyaman saat memakainya. Begitu pula dengan desain busana, karena untuk acara spesial maka, model sebaiknya terlihat cantik dan menawan dan juga warna yang digunakan sebaiknya ceria sesuai situasi acara, biasanya untuk acara siang hari menggunakan warna-warna yang ceria.

Pada (Gambar 2), menampilkan busana dengan penggunaan bahan batik, dalam proses penciptaannya busana pesta ini juga menggunakan batik. Sedangkan dalam pemilihan modelnya untuk busana anak perempuan lebih banyak menggunakan rok lingkar, agar memberi rasa nyaman pada anak-anak saat memakainya dan ada pula model busana anak dengan menggunakan celana agar memiliki variatif dalam penciptaannya.

Busana yanga akan ditampilkan kebanyakan memiliki desain yang simpel namun, nyaman saat memakainya dan tidak lupa menampilkan karakter katak pada busana pesta siang yang bersumber ide katak anak panah beracun.

\section{Ornamen}

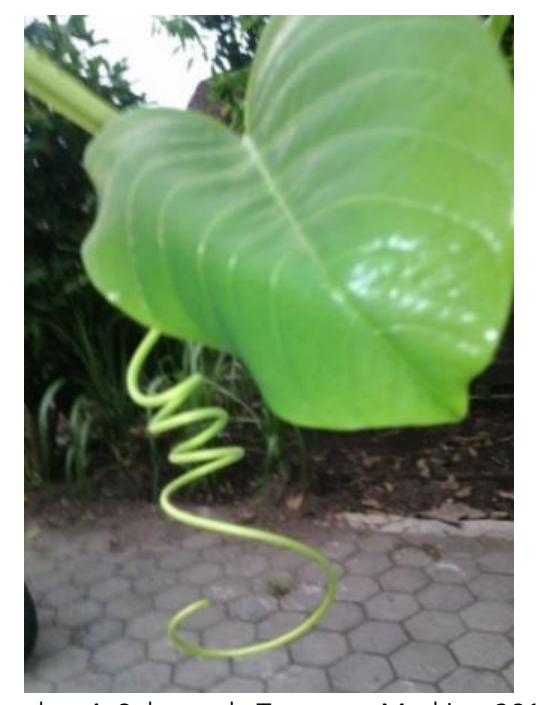

Gambar 4. Sulur pada Tanaman Markisa, 2015 (Dokumentasi: Septianti) 
Berdasarkan data acuan yang telah dikumpulkan, rancangan dalam pembuatan motifnya menggunakan karakter yang ada pada (Gambar 4) dengan menyesuaikan bentuk sulurnya sendiri akan diterapkan pada badan katak, agar memiliki nilai tradisional didalam motif katak tersebut. Sedangkan pada (Gambar 2) akan dibentuk menjadi berudu katak yang akan diletakan kelopak bunga diatas kepalanya, akan menjadi suatu gubahan antara unsur berudu katak dengan kelopak bunga agar terlihat lebih manis saat dijadikan busana anak dan akan dikombinasikan dengan batik.

Berikut merupakan proses pembuatan rancangan karya, Setelah desain terpilih mulai dibuat pola dasar anak usia 6-10 tahun.

Pembuatan pola dasar dan pecah pola digunakan untuk memperinci proses perwujudan suatu karya busana, sehingga pembuatannya lebih terarah dan teratur. Berikut beberapa ukuran anak laki-laki dan perempuan usia 6-10 tahun, sketsa alternatif, sketsa terpilih, pola dasar, dan pecah pola dengan skala 1:6 pada busana pesta siang anak:

\section{Karya 1. Red-becked Poison Frog}

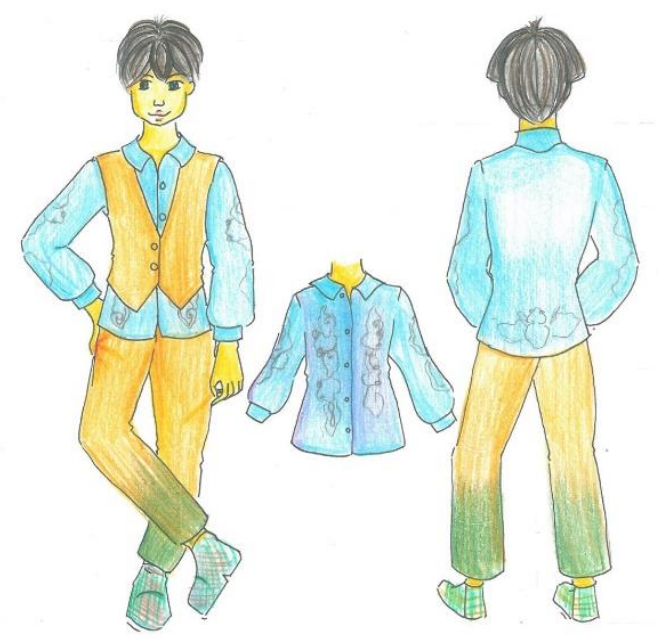

Gambar 5. Desain Busana Anak Laki-laki Karya 1

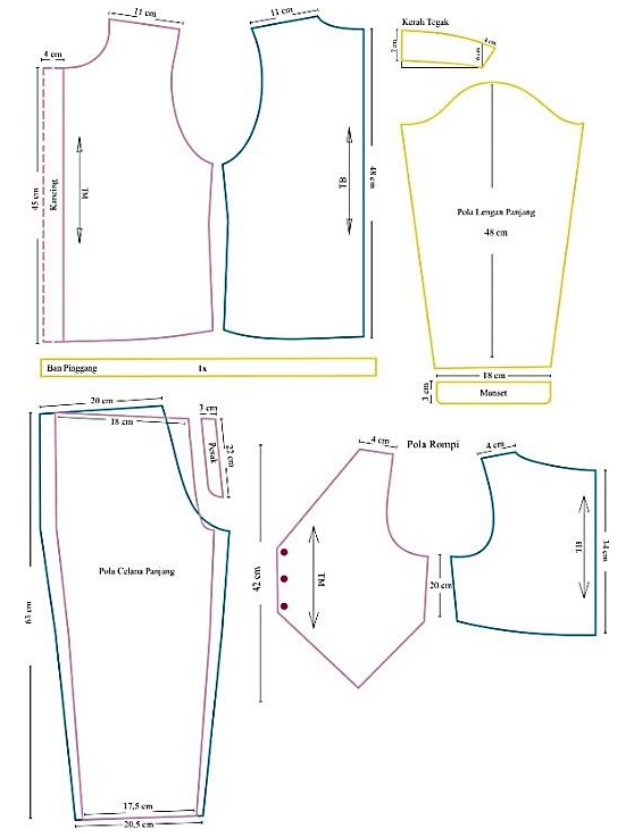

Gambar 6. Pecah Pola Kontruksi Karya 1. Red-becked Poison Frog, Skala 1:6, 2016

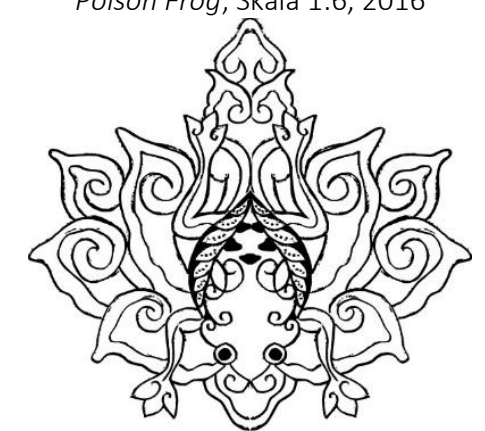

Gambar 7. Motif Katak Karya 3. Red-becked Poison Frog,

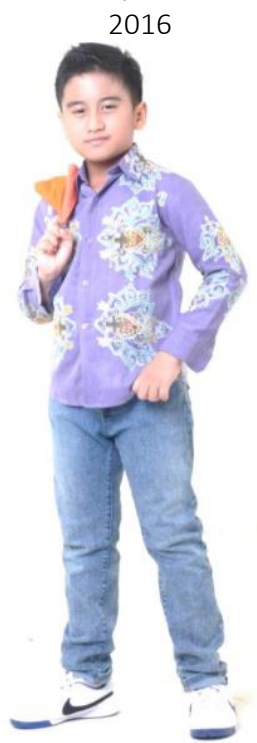

Gambar 8. Busana Anak Laki-laki Karya 1. Red-becked Poison Frog, 2016 


\author{
(Dokumentasi: Husein) \\ Judul Karya: "Red-becked Poison Frog" \\ Bahan : Kain Dobi dan Kain Katun Motif \\ Teknik : Batik Tulis dan Bordir \\ Pewarna: Naphtol dan Indigosol \\ Model : Samurai Pro Agency \\ Ukuran : Anak Usia 6-10 Tahun \\ Tahun : 2016
}

\section{Konsep Karya 1}

Red-becked Poison Frog merupakan katak yang memiliki warna yang cantik namun amat berbahaya. Warnanya melambangkan tanda berhati-hati saat akan menyentuhnya. Busana ini memiliki jenis kerah shirt dengan tambahan rompi pendek yang dipadukan dengan celana panjang. Kombinasi yang ada pada motif memberikan kesan penuh pada busana, peletakan motifnya terdapat pada lengan atas dan bawah kemeja. Dengan perpaduan tersebut memberikan kesan formal namun tetap gagah saat dipakai oleh anak-anak.

Warna orange pada rompi dan celana disamakan dengan warna batik namun tidak meninggalkan warna yang ada pada katak. Warna biru yang ada melambangkan ketenangan, orange pada rompi dan celana sebagai pembangkit semangat pada busana yang memberikan kesan gagah pada anak lakilaki yang memakainya. Warna-warnanya sendiri dapat digunakan sebagai perlambangan suatu harapan untuk meraih cita-cita yang tinggi.

\section{Karya 2. Golden Poison Frog}
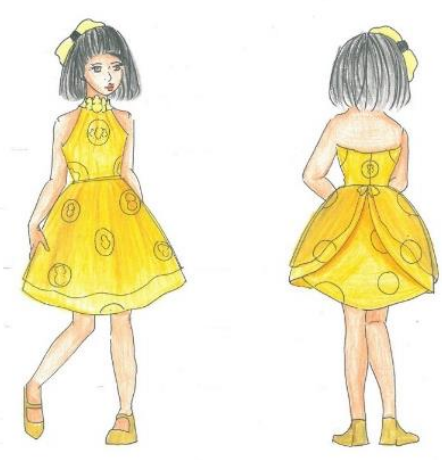

Gambar 9. Desain Busana Anak Perempuan Karya 2

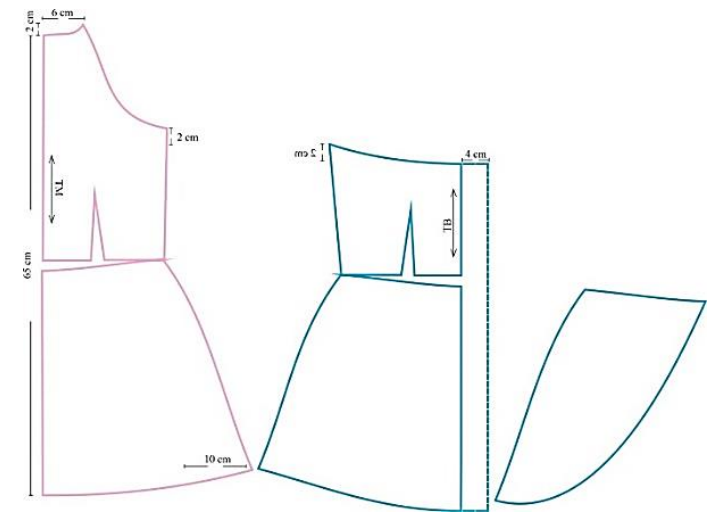

Gambar 10. Pecah Pola Kontruksi Karya 2. Golden Poison Frog, Skala 1:6, 2016

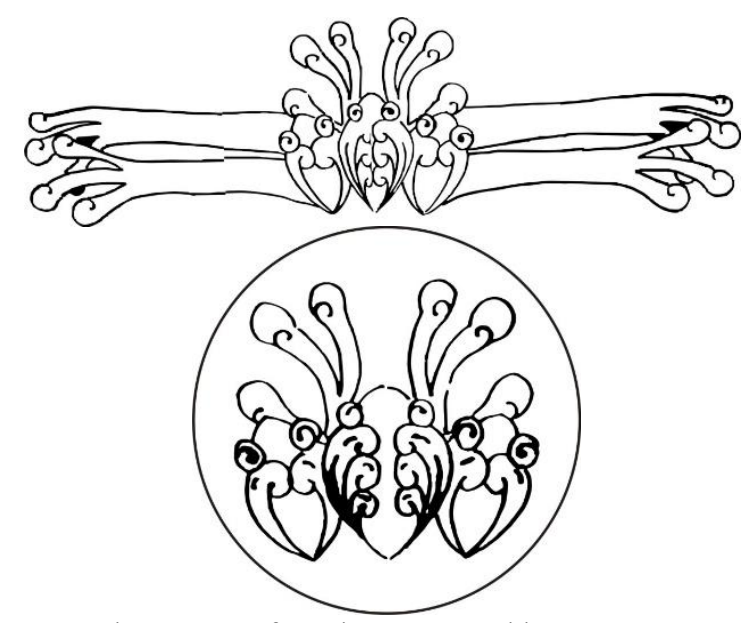

Gambar 11. Motif Katak Karya 2. Golden Poison Frog, 2016

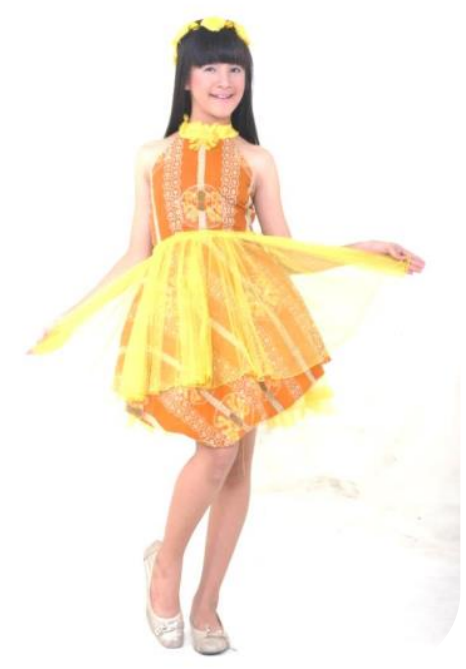

Gambar 12. Busana Anak Perempuan Karya 2.Golden Poison Frog, 2016 
(Dokumentasi: Husein)

Judul Karya: "Golden Poison Frog"

Bahan : Kain Dobi Bordir dan Kain Tile Giltter

Teknik : Batik Tulis dan Bordir

Pewarna : Naphtol dan Indigosol

Model : Samurai Pro Agency

Ukuran : Anak Usia 6-10 Tahun

Tahun : 2016

\section{Pembahasan Karya 2:}

Golden Poison Frog sesuai dengan namanya katak anak panah emas merupakan katak yang berwarna kuning atau emas di seluruh tubuhnya dan termasuk katak yang berbahaya digenusnya. Model busana A-line dengan model kerah halter pada busana memberikan kesan satu kesatuan yang seimbang. Pada bagian belakang busana rok dibentuk menjadi bentuk rok tulip yang cantik. Center of interest yang ada pada busana ditampilkan dengan motif batik yang berwarna coklat yang dipadukan dengan kombinasi kain giltter yang memberikan kesan mewah dan anggun terhadap busana. Bagian leher busana diberikan motif bordir dengan line emas agar memperlihatkan katak anak panah emas.

Warna kuning merupakan warna yang disebut sebagai warna yellow for creation atau lambang penciptaan. Kuning memberikan kesan anggun dan juga memberikan suatu energi positif pada pemakainya namun tetap memberikan kesan ceria. Warna coklat yang ada pada busana memberikan karakter natural dan kebijaksanan yang akan mendukung warna kuning, sehingga terjadinya keselarasan antar warna satu dengan lainnya.

Karya 3. Black Legged Dart Frog
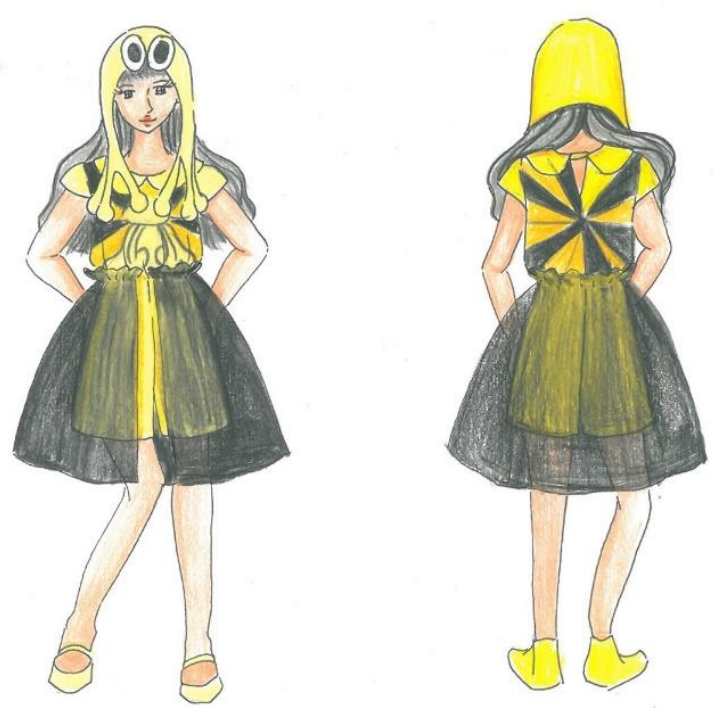

Gambar 13. Desain Busana Anak Perempuan Karya 3
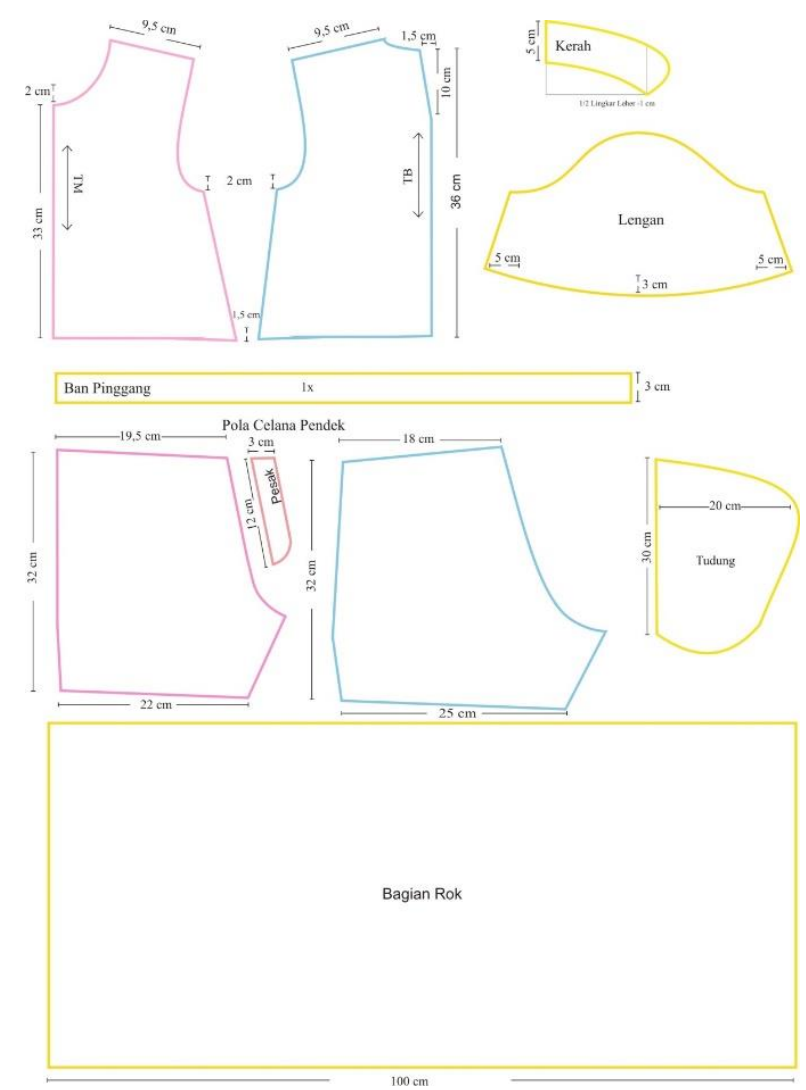

Gambar 14. Pecah Pola Kontruksi Karya 3.Black Legged Dart Frog, Skala 1:6, 2016 


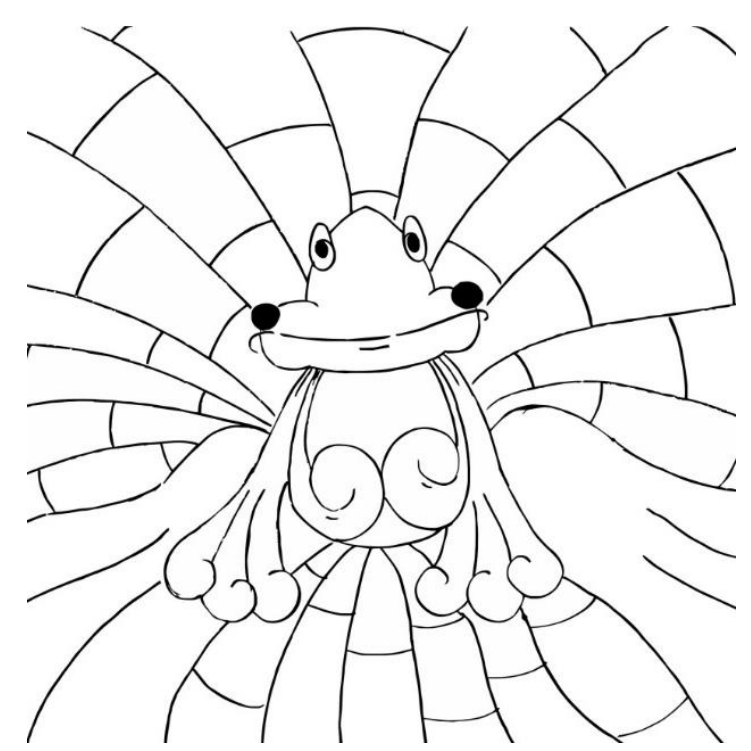

Gambar 15.Motif Katak Karya 3.Black Legged Dart Frog, 2015

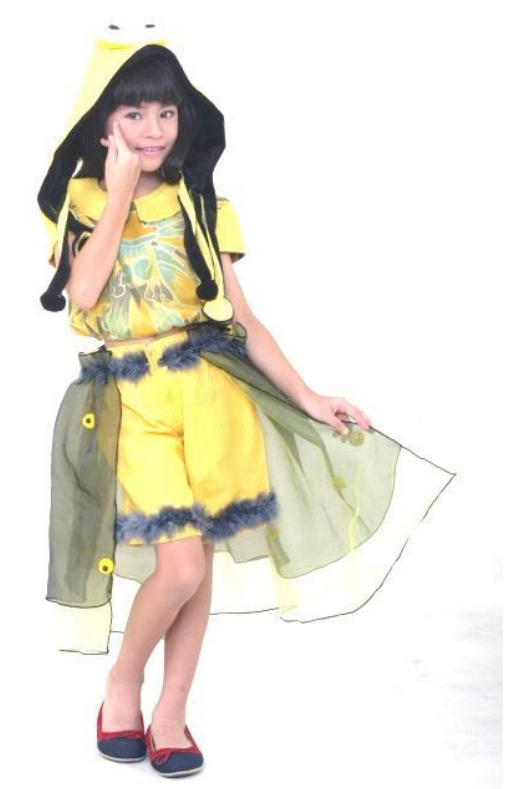

Gambar 16. Busana Anak Perempuan Karya 4. Black Legged Dart Frog, 2016

(Dokumentasi: Husein)

Judul Karya: "Black Legged Dart Frog" Bahan : Kain Dobi, Kain Organdi dan Kain Primisima Teknik : Batik Tulis dan Teknik Hias Kreasi Pewarna : Naphtol dan Indigosol Model : Samurai Pro Agency Ukuran : Anak Usia 6-10 Tahun Tahun : 2016
Pembahasan Karya 3:

Katak ini hampir sama dengan katak anak panah emas, tetapi memiliki keunikan tersendiri. Black Legged Dart Frogatau disebut juga dengan katak anak panah beracun berkaki hitam atau phyllobates bicolor, katak ini dinamai demikan karena kaki depan dan belakangnya memiliki warna gelap. Model busana dengan kerah peterpan dengan celana pendek yang dikelilingi kain organdi dengan tambahan teknik hias kreasi. Kerah peterpen dengan busana yang mengembang atau balon di bagian bawah baju, yang dipadukan dengan model setengah lengan memberikan kesan girly. Penambahan tudung pada busana dengan kombinasi kaki katak pada bagian bawah memberi kesan manis saat dipakai oleh anak perempuan.

Warna yang ada pada busana ini hanya kuning dan hitam yang disesuaikan dengan warna kataknya. warna kuning yang melambangkan kecerian sangat cocok dikenakan oleh anak-anak, dengan tambahan motif katak pada pakaian memberikan aksen yang menarik saat dilihat dan diamati. Warna hitam yang ada pada busana memberikan kesan serasi antar satu kesatuan busana. Teknik hias kreasi berbentuk telur katak menggambarkan dedikasi katak terhadap anaknya, bagaikan kasih sayang orang tua terhadap anaknya. 


\section{PENUTUP}

Karya busana pesta siang anak bertema katak anak panah beracun ini sebagai upaya untuk keluar dari pemahaman masyarakat umum mengenai katak itu menjijik dan menakutkan. Dalam karya ini diperlihatkan bahwa ada pula katak yang cantik dan indah saat diamati. Karya ini digunakan sebagai bentuk sosialisasi pada anak dan pengenalan tentang katak anak panah beracun. Busana ini didesain untuk busana pesta siang anak, dapat pula digunakan pada acara-acara tertentu.

Katak anak panah beracun sebagai sumber ide penciptaan busana pesta siang anak, menggunakan beberapa teknik dalam kriya tekstil. Empat teknik yang digunakan yaitu, batik, tye-die, bordir dan teknik hias kreasi, ketika digabungkan empat teknik tersebut terlihat serasi dan sesuai dengan busana pesta anak. Untuk mencapai keselarasan dalam penciptaan busana ini, penulis menggunakan tye-die dan batik yang disesuaikan dengan warna dan bentuk katak anak panah beracun, warnanya sendiri menggunakan warna-warna yang terdapat pada katak anak panah beracun yang digunakan sebagai sumber inspirasi dalam penciptaanya. Karena memiliki warna yang mencolok, maka karya ini memiliki daya tarik yang sesuai dengan busana pesta anak siang yang menggambarkan keceriaan anak-anak.

Dalam karya ini memiliki kekurangan pada penciptaan karyanya karena menggunakan pewarna naptol dan indigosol, sehingga warna yang dirimbulkan kurang mencolok sesuai dengan warna anak panah beracun. Penulis menyarankan bagi peciptaan busana yang ingin menampilkan warna-warna cerah menggunakan pewarna remasol untuk menampilkan warna yang lebih menarik.

Sementara itu penulis menyarankan bagi yang akan mengambil tema katak anak panah beracun dapat menggali lagi sumber data yang valid dan relevan. Agar hasil karya penciptaannya lebih bervariatif dan menghasilkan karya yang dapat menampilkan karakter dari katak anak panah beracun.

\section{Daftar Pustaka}

Agus Sachari. (2002). Estetika: Makna, Simbol, dan Daya. Bandung: ITB.

Arifah A Riyanto. (2002). Teori Busana. Bandung: YAPEMBO.

Berger, A. A. (2010). Pengantar Semiotika :Tanda-tanda dalam Kebudayaan Kontemporer. Yogyakarta: Tiara Wacana.

Goes Poespo. (2000). Teknik Menggambar Mode Busana. Kanisius: Yogyakarta.

Gustami, S. (2007). Butir-butir Mutiara Estetika Timur. Yogyakarta: Prasista.

Kay, A. (2004). 100 Pengetahuan Reptilia dan Amfibi,. In 100 Things You Should Know About Reptiles and Amphibiais. Bandung: Pakar Raya Pakarnya Pustaka.

Kusuma, D. A. (2013). Batik for Kids : Inspirasi Busana Batik yang Modis dan Fashionable untuk Anak-anak. Surabaya: Tiara Aksa.

Rani Yulianty. (2013). Ensiklopedia Dunia Amfibi. Yogyakarta: Rainbow.

Yuki. (2011). Picture of World. Retrieved August 18, 2015, from http://pictureofourworld.blogspot.co.id 


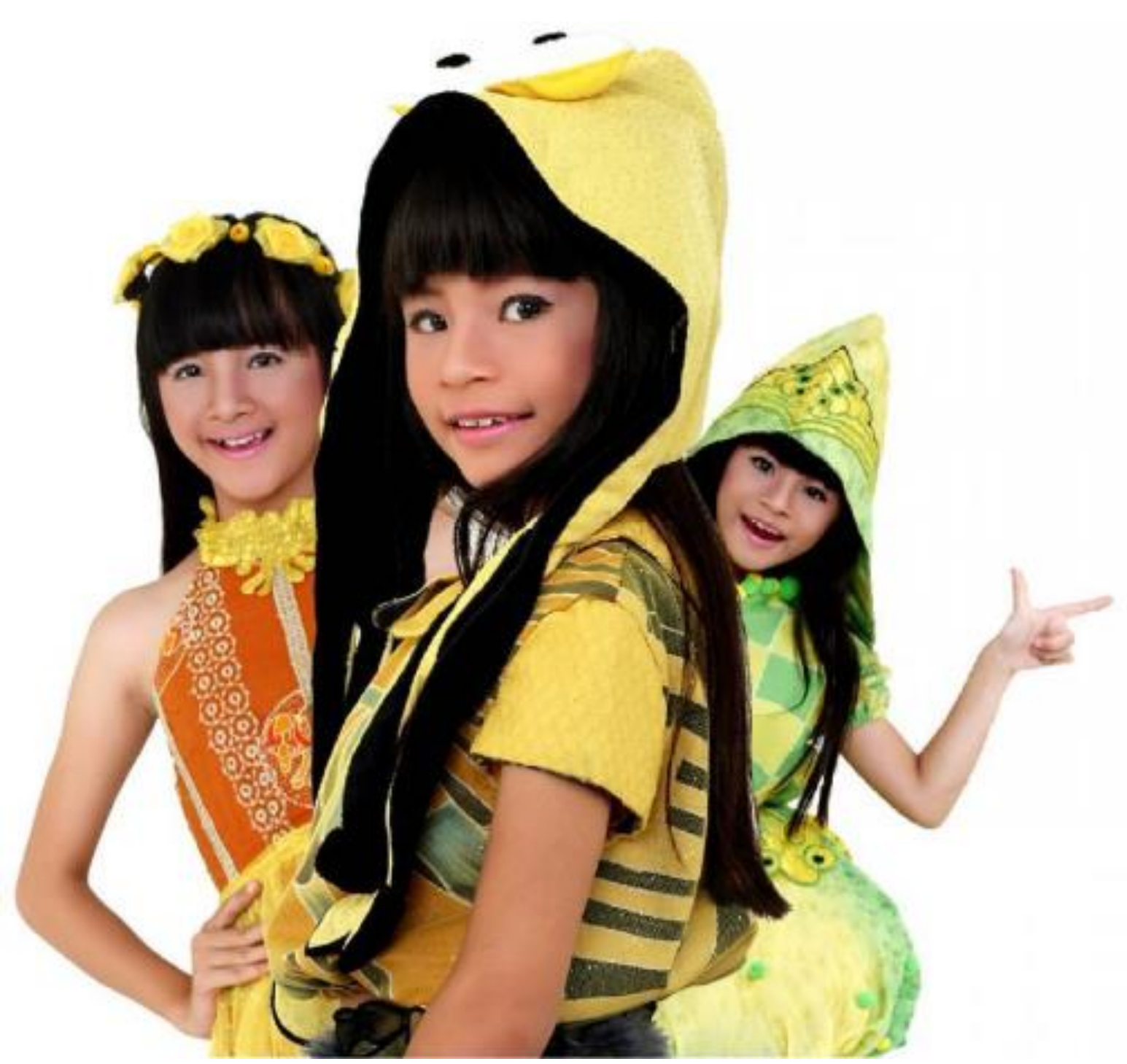

Gambar 17. Busana Pesta Siang Anak Oleh Septianti

(Dokumentasi: Husein, 2016) 